Journal of Teacher Education for Sustainability, vol. 15, no. 2, pp. 91-102, 2013

\title{
EDUCATION FOR SUSTAINABLE DEVELOPMENT IN EARLY CHILDHOOD EDUCATION IN FINLAND
}

\author{
Jyrki Reunamo and Liisa Suomela \\ University of Helsinki, Finland
}

\begin{abstract}
In the Finnish early childhood education and care (ECEC) curriculum, there is no specific content for education for sustainable development (ESD). Thus, it is not possible to get direct guidelines on how to conduct ESD in ECEC from the curriculum. We seek to look at the preferences of Finnish early childhood educators through the model of extended environmental education. Behind this model is Palmer's tree model and an emphasis on empirical, social and ethical components of ECEC. The research method employed a survey. Altogether 924 teams in Southern Finland evaluated their learning environments. By using a factor and reliability analysis, we extracted three factors relevant to the extended Palmer's model. The teachers primarily emphasised the understanding (learning) aspects of ECEC. The second most important aspect comprised the social aspects of education. The third most important aspect included the ethical and participant aspects of ECEC. Potential implications and indications to the practice of ESD are discussed.
\end{abstract}

Key words: education for sustainable development, environmental education, early childhood education and care, curriculum, learning, agency

Education for sustainable development in early childhood education in Finland

The human tendencies of environmental adaptation and agency have their roots in early childhood. The personal accommodative and participative relations to the environment have their origins in early childhood development. These basic early relations are not easily translated into education for sustainable development (ESD). Actually, a specific ESD for small children is difficult to define. However, because early childhood is fundamental for sustainable development, we have to study its educational premises. In this article, we do it by studying the emphasis on learning environment qualities in Finnish early childhood education and care (ECEC) in the light of ESD.

United Nations World Commission on Environment and Development has formulated the concept of sustainable development (Brundtland, 1987; Connelly, 2007). ESD expands the idea of environmental education (EE) to economic and social issues, and it tries to take into account ecological sustainability as well as sustainable social and economic development now and in the future (Tani, Cantell, Koskinen, Nordström, \& Wolff, 2007; Osano \& Corcoran, 2009). The United Nations World Conference on 
Environment and Development, in 1992, in Rio, declared that education is an important way of promoting sustainable development (United Nations [UN], 1992). Ten years after Rio, the UN meeting in Johannesburg (UN, 2002) had to admit that the aims of Rio had not been successful, so the United Nations Decade on Education for Sustainable Development from 2004 to 2015 was declared. According to this declaration, every nation should set out the principles of sustainable development in all national curriculums (United Nations Educational, Scientific and Cultural Organisation [UNESCO], 2005).

EE and education for sustainable development (ESD) have much in common (Osano \& Corcoran, 2009). ESD can be divided into three or four dimensions: ecological \& physical, social \& cultural and economical \& political dimensions. From the viewpoint of education, it is important to consider the learning of individuals.

The physical and ecological dimension deals with nature and the built environment. These environments we should use in a sustainable way. This means, for instance, the sustainable use of materials, food, energy and water. Part of this concerns the wellbeing of nature and how the biodiversity is taken into account. From the perspective of children, the possibilities of using open, versatile places and spaces are crucial (Kellert, 2002). Exploration, safe adventures, multidimensional ways of moving and playing are possible when the environments have a variety of affordances and children can use these affordances. This ecological dimension has a direct connection to Palmer's (1998) experimental learning in and about the environment. Palmer deals with individual learning, and, in her model, these personal dimensions include one's experiences, attitudes and values, knowledge, actions and concern about the environment.

Palmer's tree model deals with an individual's education and growth on the part of a person who takes care of the environment. What kind of "ground" and environment

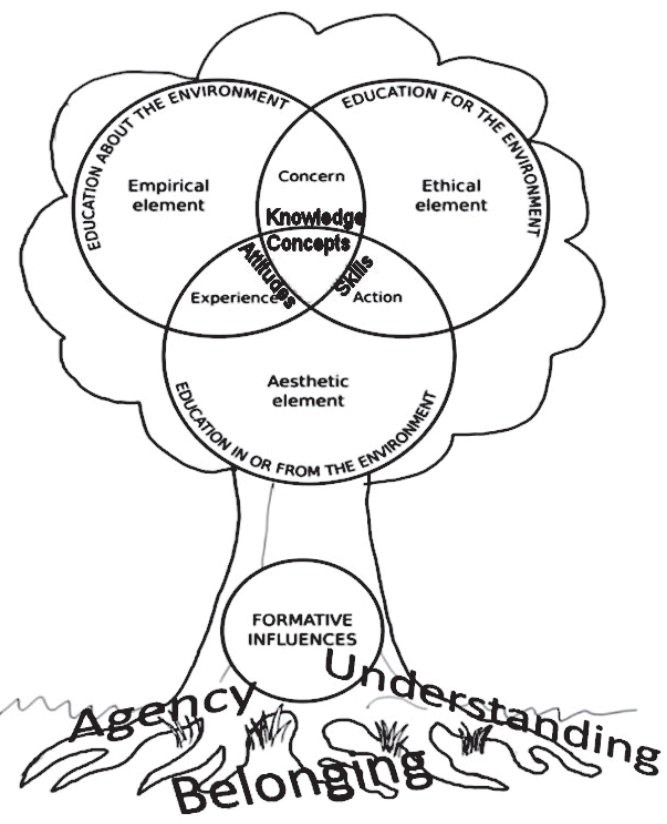

Figure 1. Palmer's extended tree model of environmental education in ECEC nourish this growing? Does the growing need special "nutrients" in early childhood? We suggest that, in early childhood, it is important to get access to sustainable, meaningful experiments of one's possibilities for participation and social education. Children's welfare, possibilities for loving, having and belonging (Allardt, 1989) all provide crucial ground in caring for one's environments. UNESCO (2005) suggested that, for instance, participatory education is one of the key educational principles in ESD.

Direct experiences in the environment form the child's emotional and ethical engagement to the place and community (Goralnik \& Nelson, 2011). Outdoors, children play, explore and interact with the environment in meaningful ways (Palmer, 1993; Ewert, Place, \& Sibthorp, 2005). In day care, this means that children are able to use their spacious outdoor and indoor environments for 
different purposes. Society, political and financial decisions, laws and even city planning enable or at worst prevent children's playing and being in their physical surroundings.

Personal experiences of place and social environments create a foundation for one's environmental beliefs and values. Sensing, positive feelings, playing and taking care of the environment are parts of these experiences. Creating positive values towards other living creatures and the physical environment depend on a number of different variables: gender, age, ethic, cultural, social and political environment and the child's possibilities for taking part in outdoor recreational activities (Teisl \& O'Brien, 2003; Johnson, Bowker, Bergstrom, \& Cordell, 2004). So, part of the personal relationship towards the environment is influenced by the interaction between the child and social \& cultural environments (Olli, Grendstad, \& Wollebaek, 2001). We learn many, if not most, of our habits from others.

Sustainable development, from the outset, requires participation and commitment from everyone (Osano \& Corcoran, 2009). We all influence social development in our different roles as playmates, consumers and members of a family and different groups in the society. In this sense, we must learn democracy early in life. To be a part of the social construction, we must be involved, committed and motivated. Concerning children, this can consist in being trained as social beings; taking notice, expressing one's own thoughts, listening to others, respecting others' opinions and others as fellow humans, cooperating, taking responsibility, reflecting and participating (Jutvik \& Liepina, 2007). A good way of practicing these skills is participation in everyday activities, taking responsibility of and taking part in planning processes and projects. Role play is a way of learning social skills and empathy.

The economical and political dimension includes the decisions, laws, rules and financial possibilities for promoting sustainable development. In day care, this means having an influence over purchases and the guidelines for sustainability.

\section{ESD in early childhood education in Finland}

Sustainable development is not addressed as such in the Finnish National Curriculum guidelines on early childhood education (2005). The environment is considered as something already built or something that the educators provide. Only in one dimension is children's active role in building their environment actually considered. This is in considering children's play environment.

There is a strong emphasis on scientific education instead of ESD in the Finnish national curriculum guidelines on early childhood education (2005). However, ESD is not only about the environment, but should also include ethical and aesthetic aspects of the environment, as Palmer (1998) describes. In Palmer's tree model, implications for EE come from different ideologies or perspectives. Palmer recommends that all the components of the EE model should be addressed in a systematic way. When we connect the ideas of Palmer to the dimensions of sustainable development, we get a model of personal and global EE. We call this an extended EE or extended Palmer's model in this article (Figure 1). It means that education about the environment, in or from the environment and for the environment should go alongside, interlinked with issue-based, actionorientated and socially critical education. A sense of being part of something that extends beyond one's own person, may be considered an important prerequisite in learning for sustainable development (Hägglund \& Pramling Samulson, 2009). 
It is not possible to get a holistic picture of ESD in ECEC just by evaluating curriculum or content orientations. ESD in early childhood is a pervasive relationship including empirical, ethical, aesthetic and social elements in relation to the environment. Young children do not yet have the prerequisites or need to understand the ecosystem from an analytical perspective. Neither do they have the need to be deeply worried or concerned about the environmental dangers and threats. Moreover, neither do they have the needed perspective to participate in the complicated societal or political decisions concerning environmental issues. However, the basic personal orientations to environmental phenomena, responsibilities and participation have their roots in children's early learning. As a prerequisite, children need tools to understand environmental phenomena, compassion and empathy for others and to practice the skills needed for environmental participation.

In this article, we try to evaluate the fundamental requisites of ESD in ECEC by studying the ECEC teachers' evaluations of their learning environment. We study the teachers' emphasis on children's different developmental issues needed for education about, for and in or from the environment.

\section{Method}

The purpose of the research is to study the relevance of teachers' preferences of ECEC in the light of ESD, more precisely in the light of the extended Palmer's model of EE. The research questions include the following:

(1) What is the emphasis of the ECEC teachers on education about the environment (knowledge and understanding - learning and learning environments)?

(2) What is the emphasis of the ECEC teachers on education in or from the environment, (the social dimension, communication and responsibility) aspects of ESD?

(3) What is the emphasis of the ECEC teachers on the education for the environment (ethical aspects and participation)?

(4) What is the emphasis of the ideas behind EE in different age groups?

\section{Participants}

The participants consisted of 787 ECEC teams and 137 childminders from southern Finland who were from eight different municipalities. Usually, there were three educators in the whole-day group and two educators in the pre-school groups. One team was usually responsible for one group. The survey was part of an official quality evaluation in the municipalities, which meant that the teams were obliged to evaluate their learning environment. The exact number of missing team evaluations is not known, but it is less than 10 percent. The childminders worked mostly alone, usually in their own homes. In the statistical analysis, the single childminders and the teams of two or three educators are all considered as teams responsible of their groups. Thus, a childminder in her home is a team of one. With childminders, the percentage of missing evaluations might be larger. In one municipality, the Swedish speaking day care centres did not participate in the evaluation. In another municipality, the private day care centres did not participate in the evaluation. It is also possible that, in some other municipalities, there were some private day care centres which did not participate in the evaluation. 
There were 686 groups with at least one child not more than three years old, 149 groups with children where the youngest child was either four or five years old and 89 groups that consisted only of pre-school children. In Finland, pre-school usually starts in the year a child turns six years old.

The number of children in day-care groups varied from eight to 30 children, the mean being 17 children. A typical situation is that under-three-year-olds have are usually found in groups of 12 children, whereas 3- to 7-year-old children in full-day care were in groups of approximately 20 children and pre-schools with 6-year-old children could number up to 25 children in the groups with several children staying only half day.

\section{Quality evaluation}

The educators evaluated the learning environment. The quality of education was evaluated by using a 57-item survey which can be retrieved from http://www.helsinki.fi/ $\sim$ reunamo/apu/LE_eval12.pdf. The evaluated aspects centred on those of harmony, chaos, objectives and possibilities. The items of evaluation included the pedagogical preferences, the atmosphere of the group, the curriculum emphasis and the practice of everyday proceedings. The Likert-scale had five degrees: 1 (does not describe), 2 (describes poorly), 3 (describes somewhat), 4 (describes quite well) and 5 (describes very well). The survey is based on a learning environment comparison between Finland and Taiwan (Reunamo, Lee, Wu, Wang, Mou, \& Lin, 2013).

Each team discussed the items together and filled out one shared evaluation. The learning environment evaluations were done between January and March 2012.

\section{Statistical analysis}

First, an explorative factor analysis was carried out to study the underlying dimensions of education. Several different methods with different number of factors and rotation solutions were applied to get a more global idea of the underlying dimensions. Different numbers of variables in the factor solution were tested to estimate the robustness of the factors. Based on the initial understanding of the underlying factors, Cronbach's alpha was used to study the intercorrelation of the items and the properties of the summary variables. With the intraclass correlation coefficients of the individual variables, the reliablility of the summary variables was evaluated. With reliability, we can get an overall index of internal consistency on each summary variable. During the reliability analysis, the summary variables were formed.

\section{Ethical considerations}

This research has been part of a research and development project designed to empower both the educators and the children. The educators have been considered as research colleagues in the dissemination of the research results. The educators were given feedback on tools for developing their work based on the research findings. The teams have received tools for pedagogical evaluation, where each team has also received feedback on their own group's activities and interaction based on the preliminary results. The English web-pages of the project are available at: http://blogs.helsinki.fi/orientate/. 


\section{Results}

The results are based on the educational quality evaluation of the ECEC teams. We concentrate on the three summary variables (Table 1 ) that are related to the extended Palmer's model. We leave the harmonious, curriculum and chaotic summary variables out of this analysis, because they concentrate mainly on the atmosphere and curricular aspects of the educational quality which are not part of the extended Palmer's model.

Table 1. The main factors of the ECEC learning environment

\begin{tabular}{lcc}
\hline Learning environment quality & Summary variable mean & $\begin{array}{c}\text { Summary variable } \\
\text { standard deviation }\end{array}$ \\
\hline Learning & 3.78 & 0.57 \\
\hline Social relations & 3.43 & 0.61 \\
\hline Participation & 3.16 & 0.74 \\
\hline
\end{tabular}

The educators emphasised learning the most (Table 1). Its standard deviation was the smallest. This means that the educators were the most unanimous about the importance of learning. The second most important emphasis was on social relations, and it had almost as small standard deviation as learning. The participative aspects of the learning environment were emphasised the least, and the teams' emphasis deviated from each other the most.

Table 2. The means and standard deviations of the variables in the summary variable of learning

\begin{tabular}{lcc}
\hline \multicolumn{1}{c}{ Variables in the learning summary variable } & Mean & Standard deviation \\
\hline $\begin{array}{l}\text { Children's learning and skill development is } \\
\text { evaluated in a versatile way }\end{array}$ & 4.01 & 0.79 \\
\hline $\begin{array}{l}\text { Our space has been divided into many smaller } \\
\text { corners and activity spots }\end{array}$ & 3.9 & 1.05 \\
\hline $\begin{array}{l}\text { The learning and activity environment are versatile } \\
\begin{array}{l}\text { Children's thinking, problem solving and learning } \\
\text { to learn are flourishing in our group }\end{array}\end{array}$ & 3.79 & 0.78 \\
\hline $\begin{array}{l}\text { The physical learning environment (space and } \\
\text { materials) involves children in their activities }\end{array}$ & 3.55 & 0.84 \\
\hline
\end{tabular}

The reliability of the summary variable of learning (Table 2) estimated with Cronbach's alpha was .645, which is satisfactory. In the summary variable of learning, the importance to monitor children's development is highlighted. The teachers have a tendency to divide the activities in different activity spots and materials, and the metacognitive aspects of development are important. The largest differences among groups were the division of the activity spots.

The summary variable fits with Palmer's idea of education about the environment. The result describes the teachers' emphasis on the environment. However, we are not sure what elements of the environment are included or how far from the classroom the evaluated learning environment extends. Learning was the most highly valued aspects of ECEC. In Table 3, the variables included in the summary variable of social relations are presented. 
Table 3. The summary variable of social relations: the means and standard deviations of the included variables

\begin{tabular}{lcc}
\hline Variables in the social relations' summary variable & Mean & Standard deviation \\
\hline $\begin{array}{l}\text { There is a strong togetherness and consideration } \\
\text { towards others in the group }\end{array}$ & 3.88 & 0.8 \\
$\begin{array}{l}\text { The social relations between children are very } \\
\text { functional and develop well }\end{array}$ & 3.76 & 0.8 \\
\hline $\begin{array}{l}\text { The children take responsibility in the daily tasks } \\
\text { Children obey rules without educator's supervision }\end{array}$ & 3.66 & 0.96 \\
\hline $\begin{array}{l}\text { There is a lot of drama plays (performances, plays) } \\
\text { in the group }\end{array}$ & 2.83 & 0.96 \\
\hline
\end{tabular}

The Cronbach's alpha describing the intra-class correlations was .700, which is satisfactory. In the summary variable of social relations, the peer relations are important. The consideration towards others is strong, the social relations develop well, the children take responsibility and follow rules without supervision. It is interesting that role playing clearly belongs to this summary variable. In role playing, the formation of social roles is essential (Reunamo et al., 2013).

The social summary variable makes sense in the extended Palmer's model. According to Palmer, what is essential in education in or from the environment are the experiences based on senses and observation. When the experiences are shared with others, the experiences include social content and can be used in social development. When children live in a learning environment that is filled with consideration, responsibility and togetherness, the children can get an experience of a shared environment valued by everybody. Children's experiences can include a shared responsibility. The third summary variable is participation, which is described in Table 4.

Table 4. The summary variable of participation: the means and standard deviations of the included variables

\begin{tabular}{lcc}
\hline Variables in the participation summary variable & Mean & Standard deviation \\
\hline $\begin{array}{l}\text { The adults consider children's views in the } \\
\text { development of the activities }\end{array}$ & 3.74 & 0.83 \\
\hline $\begin{array}{l}\text { Children have been given possibilities to impact } \\
\text { the daily activities }\end{array}$ & 3.45 & 0.88 \\
\hline $\begin{array}{l}\text { Different projects and themes are developed often } \\
\text { together with children }\end{array}$ & 3.01 & 1.03 \\
\hline $\begin{array}{l}\text { Children's plays last and develop often for weeks } \\
\text { Children participate in many ways in the planning } \\
\text { of the activities }\end{array}$ & 2.91 & 1.15 \\
\hline
\end{tabular}

The Cronbach's alpha describing the inner consistency of the summary variable is .815, which is the highest intra-correlation of the summary variables. This means that participation is the tightest package. At the same time (Table 1), participation had the largest deviation among groups. This means that groups are different in their emphasis on participation, but, if they have participative qualities, they tend to have all the qualities described in Table 4. 
When the learning is participative, the children's views are taken into consideration. Children have possibilities to develop their own plays and ideas for long periods of time. Children also participate in the planning of the activities although children's planning is having the least emphasis of the variables.

The participative summary variable describes well the education for the environment in the extended Palmer's model. When children learn to impact their learning environment, they probably also learn to participate in the environment on a larger scale later. When children can learn from early on that their ideas, values and actions matter, they get used to participating in the steering of the dynamics of the environment. Learning about the environment for young children involves concrete actions in which they experience making meaningful changes in the course of events. Children learn that their deeds have consequences. When children practice the planning of the learning environment from as early as possible, they learn that their ideas impact the environment. The mean for the participative summary variable was the lowest which means that education for the environment was not emphasised as much as the two other aspects of the extended Palmer's model. In Table 5, we have acquired a perspective how the different emphasis on summary variables changed as children grew older.

Table 5. The means of the main factors in each age group

\begin{tabular}{lccc}
\hline & $\begin{array}{c}\text { Youngest child } \\
\text { in the group is } \\
\text { 1-3-years-old }\end{array}$ & $\begin{array}{c}\text { Youngest child } \\
\text { in the group is } \\
\text { 4-5-years-old }\end{array}$ & $\begin{array}{c}\text { Youngest child } \\
\text { in the group is } \\
\text { 6 years old }\end{array}$ \\
\hline Participation & 3.08 & 3.34 & 3.53 \\
\hline Social relations & 3.34 & 3.64 & 3.83 \\
\hline Learning & 3.73 & 3.91 & 3.96 \\
\hline
\end{tabular}

As we can see in Table 5, learning (education about the environment) was emphasised in all age groups. The difference between age-groups in learning was mainly due to the variable Children's thinking, problem solving and learning to learn are flourishing in our group. For the youngest group, the mean was $3.51(S D=.84)$, for the second group $3.94(S D=.71)$ and for the oldest group $4.05(S D=.82)$. The importance of metacognition increased as children got older. It can be interpreted that children get more versatile skills to steer their learning. As children become more conscious about their learning, they acquire tools that also influence their personal orientation to the environment.

According to Table 5, the importance of social relations (education in or from the environment) increased strongly as children get older. The variable The children take responsibility in the daily tasks increased the most: in the youngest group, the mean was $3.48(S D=.97)$, for the second youngest group, the mean was $4.14(S D=.68)$, and, for the pre-school group, it was $4.24(S D=.77)$. The increase was sharp between the youngest and second youngest groups. Perhaps the youngest children are not yet ready for personal responsibility. Thus, it may not be wise to require environmental responsibility from young children. However, even in the youngest group, the item There is a strong togetherness and consideration towards others in the group had a high mean $(3.87, S D=.81)$. It can be argued that social responsibility is best nourished in a learning environment with strong togetherness and consideration. Even though we cannot demand environmental responsibility from the youngest children, education in a socially responsible environment embeds seeds of responsibility in the schemas children learn. 
Participation had the lowest mean in all age groups (Table 5). This means that participation was not valued as much or it was not seen as an essential ingredient in education as other factors. The education for environmental change is not seen as central to ECEC. The largest difference between the groups was for the item Children participate in many ways in the planning of the activities. In the youngest group, the mean was only $2.60(S D=1.01)$ in the second youngest group $2.84(S D=.87)$, and, in the preschool group, the mean was $3.22(S D=.62)$. It is quite natural that the youngest children with their short attention span and their tendency to find meaning in the present does not provide needed skills for long-term planning of activities. Nevertheless, in the item The adults consider children's views in the development of the activities the mean for the groups with the youngest children got as high as $3.70(S D=.85)$, which is the same as for the groups with older children. From the participative perspective, this can be interpreted that sensitive teachers help young children express their ideas for others to interact with. If the teachers can help young children to transform their intentions into concrete actions, it helps these children to grasp the connection between their motives and reality. This is the beginning of education for environment where concern meets action.

\section{Discussion}

There is always the possibility that the respondents answer the survey in a way they think they should answer. This means that the results may seem better than the reality in the kindergarten or with childminders. There is no easy way to measure the real conduct of ESD. According to Chatzifotiou (2006), EE and ESD are connected and may have similar problems. The problems may stem from an insufficient introduction to the limited knowledge and information teachers seem to possess in terms of their practices and their understanding of how new developments can procure continuity with what they are already doing. The tacit knowledge of ESD in ECEC makes the evaluation even harder. Even though the discussion about ESD in ECEC may be viewed as marginal, and the research done on the subject scarce, a historical, philosophical connection to nature-based learning in the early years can be derived already from the early philosophical works of Froebel (Edwards \& Cutter-Mckenzie, 2011).

According to Ärlemalm-Hagsér and Sandberg (2011), educators face a general dilemma: they never know what children need to know in order to meet a changing future. It is a task for pre-school staff to address these challenges and create meaningful learning activities for their charges. Through an approach where the variety of voices of the children are listened to, multi-faceted topics such as democracy, citizenship, diversity, social and economic justice, responsibility, care, respect, tolerance and peace can generate a fruitful educational environment in pre-schools. According to Sandberg and ÄrlemalmHagsér (2011), play is important in mediating these values.

The emphasis on education about the environment (knowledge and understanding learning and learning environments) was the strongest among ECEC teachers. Also its deviation was the smallest which means that the ECEC teachers share this high value of learning. The emphasis on education in or from the environment (the social dimension, communication and responsibility) was also highly valued, and its deviation was also quite small. The emphasis on the education for the environment (ethical aspects and participation) was the weakest. However, the teachers deviated in their emphasis the 
most which means that some teachers tended to have different values concerning participation.

When we consider ESD for the youngest children, we do not consider understanding the laws of nature or development. We do not regard young children as responsible for the environmental change. Perhaps the best way to introduce young children to sustainability is by being a good role model (Siraj-Blatchford, 2009). We do not treat young children as if they should have sustainability on their minds as they play away in their busy everyday. However, this lack of knowledge, attitudes and skills to consider sustainable development does not mean that early childhood is not important for sustainable development. The younger the children have access to experiences of steering their learning and motives, the better equipped they are to have the needed perspective in the changes of tomorrow. The more warmth and concern in their nearest contacts the children encounter, the more concretely children can feel their belonging within a shared, even global, society. The more children's ideas are taken into account and brought into the open, the more practice children get in making the environment better. The fundamental experiences of belonging, understanding and agency have their roots in early childhood. These early fundamental experiences give weight to later aspirations. When children get older, their knowledge and intellectual skills increase rapidly. But without a balanced development of the roots, the overall development cannot be sustainable.

The extended Palmer's model cannot be traced directly in the curriculum, pedagogy or learning of early childhood. Nevertheless, while extending the model with the dimensions of sustainable development, it seems to fit surprisingly well with the practical aspect of ECEC.

The survey questions were lacking the political and societal aspects of sustainable development. The focus of the questions was in evaluating the practices of the day-care unit, not the instructions the unit had from the social services department and so on. Different municipalities have various emphases on sustainable development, for instance, the city of Espoo tries to integrate sustainable development as a part of education and everyday practices in day care (Sustainable Development Espoo [RCE]), 2013). But part of the crucial skill of learning participation is also part of the political and societal aspects. And the lower emphasis on the participation (education for environment) dimension in the results raises some questions. If we want children to be equipped to cope with the fast-paced environmental changes of the future, children need to experience their own impact on the environment. Children need to practice seeing how their ideas evolve into action. Children need to practice sharing their initiatives with others and see that their initiatives have an effect on the shared environment. The more rapid the changes are in the future, the more important it will be that children learn to work together and see the consequences of their actions. We may not wait for children to become old enough to participate. By helping children to bring their ideas and motives out into the open for others to work on makes it possible for children to develop their participative skills. By helping children to experience the impact of their initiatives, we help children to develop dynamic ideas that can have real effects on the environment.

ESD for the youngest children should not be invisible or neglected. If young children learn the fundamental fact that their thoughts and actions matter, that learning can be embedded as an ingredient to all the other knowledge that children learn later on. Without that basic learning sustainable development is powerless. We would like to complement Palmer's model with an emphasis on the roots, without which the tree cannot survive. 


\section{References:}

Allardt, E. (1989). An updated indicator system: Having, loving, being (Working paper). Helsinki: University of Helsinki.

Ärlemalm-Hagsér, E., \& Sandberg, A. (2011). Sustainable development in early childhood education: In-service students' comprehension of the concept. Environmental Education Research, 17(2), 187-200.

Brundtland, G. (Ed.). (1987). Our common future: The world commission on environment and development. Oxford: Oxford University Press.

Chatzifotiou, A. (2006). Environmental education, national curriculum and primary school teachers. Findings of a research study in England and possible implications upon education for sustainable development. Curriculum Journal, 17(4), 367-381.

Connelly, S. (2007). Mapping sustainable development as a contested concept. Local Environment: The International Journal of Justice and Sustainability, 12(3), 259_ 278.

Edwards, S., \& Cutter-Mackenzie, A. (2011). Environmentalising early childhood education curriculum through pedagogies of play. Australasian Journal of Early Childhood, 36(1), 51-59.

Ewert, A., Place, G., \& Sibthorp, J. (2005). Early-life outdoor experiences and an individual's environmental attitudes. Leisure Sciences: An Interdisciplinary Journal, 27(3), 225-239.

Goralnik, L., \& Nelson, M. (2011). Framing a philosophy of environmental action: Aldo Leopold, John Muir and the importance of community. Journal of Environmental Education, 42(3), 181-192.

Hägglund, S., \& Pramling Samuelsson, I. (2009). Early childhood education and learning for sustainable development and citizenship. International Journal of Early Childhood, 41(2), 49-63.

Johnson, C. Y., Bowker, J. M., Bergstrom, J. C., \& Cordell, H. K. (2004). Wilderness values in america: Does immigrant status or ethnicity matter? Society \& Natural Resources, 17(7), 611-628.

Jutvik, G., \& Liepina, I. (Eds.) (2007). Education for change. A handbook for teaching and learning sustainable development. Retrieved February 26, 2013, from http://www.balticuniv.uu.se/index.php/component/content/article/124-educationfor-change-teaching-materials/336-the-educ-teaching-materials

Kellert, S. (2002). Experiencing nature: Affective, cognitive and evaluative development in children. In P. H. Kahn \& S. Kellert (Eds.), Children and nature, psychosocial, sociocultural and evolutionary investigations (pp. 117-151). Cambridge: The MIT Press.

National curriculum guidelines on early childhood education and care in Finland. (2005). Retrieved February 26, 2013, from http://urn.fi/URN:NBN:fi-fe201204193910.

Olli, E., Grendstad, G., \& Wollebaek, D. (2001). Correlates of environmental behaviors: Bringing back social context. Environment and Behavior, 33(2), 181-208.

Osano, P. M., \& Corcoran, P. B. (2009). Introduction. In P. B. Corcoran \& P. M. Osano (Eds.), Young people, education and sustainable development (pp. 21-33). Wageningen: Wageningen Academic Publishers.

Palmer, J. A. (1993). Development of concern for the environment and formative experiences of educators. Journal of Environmental Education, 24(3), 26-31. 
Palmer, J. A. (1998). Environmental education in the $21^{\text {st }}$ century: Theory, practice progress, promise. London: Routledge.

Reunamo, J. T., Lee, H. C., Wu, R., Wang, L. C., Mou, W. Y., \& Lin, C. J. (2013). Perceiving change in role play. European Early Childhood Education and Research Journal, 21(2), 292-305.

Sandberg, A., \& Ärlemalm-Hagsér, E. (2011). The Swedish national curriculum: Play and learning with fundamental values in focus. Australasian Journal of Early Childbood, 36(1), 44-50.

Siraj-Blatchford, J. (2009). Editorial: Education for sustainable development in early childhood. International Journal of Early Childhood, 41(2), 9-21.

Sustainable Development Espoo (RCE). (2013). Sustainable Development Programmes of Schools and Day Care Centres. Retrieved February 26, 2013, from http://www.espoo.fi/en-US/Housing_and_environment/Environment_and_nature/ Sustainable_Development_Espoo_RCE/Sustainable_Development_Programmes_ of_Schools_and_Day_Care_Centres.

Tani, S., Cantell, H., Koskinen, S., Nordström, H., \& Wolff, L. A. (2007). Kokonaisvaltaisuuden haaste: näkökulmia ympäristökasvatuksen kulttuuriseen ja sosiaaliseen ulottuvuuteen [The challenge of the big picture: Perspectives into the cultural and social dimensions of environmental education]. Kasvatus, 38(3), 199-211.

Teisl, M., \& O’Brien, K. (2003). Who cares and who acts? Outdoor recreationists exhibit different levels of environmental concern and behavior. Environment and Behavior, 35(4), 506-522.

UN (United Nations). (1992). Agenda 21. New York: United Nations.

UN (United Nations). (2002). World summit on sustainable development - implementation plan. Retrieved December 6, 2013, from http://www.johannesburgsummit.org/ html/documents/documents.html

UNESCO (United Nations Educational, Scientific and Cultural Organisation). (2005). UN Decade of Education for Sustainable Development. Paris: UNESCO.

\section{Correspondence:}

Jyrki Reunamo, Ph.D., Department of Teacher Education, University of Helsinki, P.O. Box 9, FI-00014 University of Helsinki, Finland. Email: jyrki.reunamo@helsinki.fi 